\title{
THE ROLES OF LEADERSHIP PRINCIPAL TO IMPROVING OF EDUCATION QUALITY
}

\author{
Wisnu Dwi Wibowo ${ }^{1 *}$, Wakhudin ${ }^{2}$ \\ Universitas Muhammadiyah Purwokerto, INDONESIA
}

Received 31 May 2021 - Revised 29 August 2021 • Accepted 20 September 2021

\begin{abstract}
This study aims to describe the leadership process of principals with managerial competencies to improve the quality of education in primary schools. Initial observations show that there are still many school principals in the Adipala sub-district, Cilacap, who have not carried out their primary duties and functions correctly as leaders of educational units. The principal is the person who is responsible for and leads the school in managing school resources to achieve academic goals. The method used in this research is a qualitative approach to phenomenological studies. The informants in this study were five public elementary school principals in the Adipala sub-district. Data collection techniques by interview, observation, and study documentation. Activities in data analysis are data reduction, data presentation, and concluding. The results showed that principal leadership with excellent and practical managerial competence could improve the quality of education in primary schools.
\end{abstract}

Keywords: Principal Leadership, Education Quality, Managerial Competence, elementary school

\section{INTRODUCTION}

The development of education in Indonesia cannot separate from the components of education that are integrated in an integrated manner to achieve the goals of national education. Quality schools in providing their services are one of the keys to success in achieving national education goals. The quality of education in schools cannot separate from the professional management and leadership of the school principal. Schools that cannot show the best quality in their educational services will be abandoned by the community, in this case, the students' parents/guardians.

"Leader as the individual in the group is given the task of directing and coordinating task- relevant group activities." [1]. This definition states that a leader is a member of a group who can direct and coordinate performance to achieve goals. The principal is a professional leader in the school or education unit who is in charge of managing school resources and collaborating with teachers, staff, and other employees in educating students to achieve educational goals [2]. The quality of education is everything that includes the input, process, and output of education [3]. Academic input is anything that affects the ongoing process of education, which contains resources, software, and expectations in the form of a vision, mission, and goals to achieve by the school. The educational process is the changing of something into something else. The learning process at school is at the highest level compared to other techniques. The output of education is school performance in the form of school achievement due to the learning process.

The competence of the principal relating to the management of school resources is managerial competence. Good school management with good principal organizational abilities will also result in high-quality education. Competence is the ability to carry out or perform a job or task which is based on skills and knowledge and support by the work attitude demanded by the assignment [4]. Managerial competence is a specific type of individual competence, namely the activities, attitudes, knowledge, skills, and personal characteristics needed to improve management performance [5].

The acceleration of the flow of information, globalization, and the multidimensional crises that hit the Indonesian nation has made it difficult to find an ideal leader who has a high commitment to his primary duties and functions [6]. Many leaders are not worthy of carrying out their leadership mandate, including in the world of education. Many principals in their leadership do not have a clear vision, mission, and goals in improving the quality of education in their schools. Therefore, an ideal school principal is needed to improve the quality of education. 
Empirical facts and preliminary observations show that there are several Principals of Public Elementary Schools in Adipala District who have not carried out their primary duties and functions correctly as leaders of educational units. This phenomenon, in addition to the sub-standard appointment of principals, also caused by the poor performance of the principal, such as lack of motivation to work, lack of motivation, lack of commitment to the job, financial situation, age was nearing retirement, less proficient in the use of Information and Communication Technology and several other inhibiting factors that trigger the low performance of the principal resulting in the quality of education in schools.

The leadership of the principal in the area of the Regional Coordinator for Education in the Adipala District, when viewed from the managerial competence, varies greatly. There are school principals who have high, medium, and even low managerial competence. One of the factors of managerial competence possessed by the principal can be seen from the appointment procedure. The researcher wanted to find the meaning of the principal's leadership process in improving the quality of education in his school seen from the managerial competence possessed by the principal based on the background of his appointment procedure. The purpose of this study was to describe the leadership process of principals with managerial competencies to improve the quality of education in primary schools.

\section{METHOD OF THE RESEARCH}

The research method used by researchers is a qualitative research approach. Qualitative research is research to understand the phenomenon of what is experienced by research subjects holistically using descriptions in the form of words and language in a particular natural context and by utilizing various natural methods [7]. The type of research used by the researcher is a phenomenological study. Phenomenology was first pioneered by Edmund Husserl around the 1900s. Phenomenology in a broad sense is the science of symptoms or anything that appears. In contrast, in a narrow sense, phenomenology is the science of symptoms that manifest themselves in human consciousness [8]. Phenomenology is a research design that comes from philosophy and psychology where researchers describe the experience of human life about a particular phenomenon described by informants [9].

This research conduct in SD Negeri in Adipala District, Cilacap Regency. This research conduct from April to May 2021. The research subjects were informants who provided information and data needed by researchers when the study was carried out in the field. The research subject is a part that represents a population and uses specific techniques [10]. The informants in this study were 5 Principals of Public Elementary Schools in the Regional Office of Education, Adipala District, Cilacap Regency, with several different criteria based on their appointment procedures and managerial competencies.

The data collection techniques used were interviews, observation, and documentation study. The primary data obtained by in-depth interview techniques, while other data such as observation and documentation only used as supporting data. An interview is a conversation with a specific purpose carried out by two parties, namely the interviewer who asks the question and the interviewee to provide answers to the questions given [11]. The interview used in this study is an in-depth interview with an unstructured interview form.

The techniques of analysis data in this study is Miles and Huberman Model. Activities in data analysis must carry out interactively and continuously until the data obtained is saturated [12]. Activities in data analysis, namely data reduction, display data, and conclusion drawing/verification.

\section{RESULT AND DISCUSSION}

The principal has a very central role in leading and managing the education unit. Principals of Public Elementary Schools in Adipala Subdistrict, Cilacap Regency, in general, when viewed from the varied managerial competencies, some have high, medium, and even low managerial competence. Main managerial competencies include:

a. The ability to compile school planning for various levels.

b. Able to develop school organizations as needed.

c. Able to lead teachers and staff to optimize human resources.

d. Able to manage teachers and staff to optimize human resources.

e. Able to manage school facilities and infrastructure [13].

Professional school principals with good managerial competence can be produced through a recruitment process that is carried out in a professional, transparent and accountable manner [14]. One of the various managerial competencies possessed by the Principals of Public Elementary Schools in Adipala District can be seen from the appointment procedure. In general, the guidelines for the appointment of school principals in Cilacap Regency still (C) 2021 by the authors; licensee PGSD UMP. This artic 28 of 2010 as replaced by Permendikbud Number 6 of 2018 and conditions of the Creative Commons Attribution License (http://creativecommons.org/licenses/by/4.0/). 
concerning the Assignment of Teachers as School Principals. The Regulation of the Minister of Education explains that the selection of prospective school principals goes through two stages, namely administrative selection and substance selection. If declared to have passed the two stages, the future school principal has the right to participate in the education and training of the Prospective School Principal or the Preparation Program for the Prospective School Principal to obtain a Certificate of Completion of Education and Training. Appointment of school principals conducted for Prospective School Principal has had a Graduate Certificate of Education and Training Prospective School Principal. Teachers are assigned to be the principal at SD Negeri the District Adipala, Cilacap many who are appointed and sworn in first to headteachers without training Prospective School Principal and yet have a Certificate of Graduate Education and training of the standards become headmaster. This contradicts and violates existing procedures, as conveyed by EM from SDN PD 02:

"At that time at the end of 2018, I was proposed to be the principal of the school and then asked to file a filing and take a written test in the district, but the results were not announced whether they passed or not, suddenly in July 2019 there was a call from the Cilacap Regent to take part in the inauguration and oath of office of the principal. The foundation of the country in the Pendopo. I was appointed without going through the education and training of Prospective School Principal and did not have a Certificate Principal. Until now, I have not had the opportunity to take part in training to strengthen school principals. However, I cannot refuse the task from the Regent."

The appointment and inauguration of the principal is the policy and the authority of the head of the region with consideration of stakeholders within the Department of Education and Culture and noticed many vacancies Principal at SD Negeri. Following up on the policy, the Department of Education and Culture of Cilacap cooperation with Lembaga Pengembangan dan Pemberdayaan Kepala Sekolah dan Pengawas Sekolah (LP2KSPS) and Lembaga Penjaminan Mutu Pendidikan (LPMP) to organize a program of strengthening principals to principals who are being served but uncertified head schools and do not have a School Principal Register Number with the intention of increasing the competence of the school principal a learning leader in academic units. The fact is that not all public primary school principals have had the opportunity to take part in the training to strengthen school principals.

Principals who inaugurate without going through Education and Training for Principal Candidates in the field have moderate and even low managerial competence in improving the quality of education in their schools. Based on the results of an interview with one of the school principals who was appointed without going through training in 2019 with the initials MK from SDN AK who said the following:

"During my two years as principal of the school, I had difficulty managing the school, especially now that everything is completely online and I am not very good at using a laptop. Being the principal of a school is a tough responsibility. If possible, I want to be a teacher again. Fortunately, I was placed in a school that has smart teachers and master information and communication technology."

The low competence of principals is partly due to the fact that the principal recruitment process is not fully open, the selection is not through the correct rules, the periodization is not according to the rules, the lack of evaluation of the principal's performance appraisal, and the limited forum for the professional development of the principal [15]. The same thing was conveyed by NN as the head of SDN DP 01, who appoint without going through the Education and Training procedure for Principal Candidates in 2014, but when he was the principal, he had the opportunity to participate in strengthening school principals in 2019. NN conveyed the following:

"Recently, I lost the school operator because I left and appoint as a village official. Usually, he does all school administration. As if the school operator is the backbone of the school. I am now confused about doing the administration and school programs that are so many. Usually, all the work on the operator. I have to ask even, without being told, it will be done automatically. I hope that as soon as possible, there will be teachers who are public, young, and capable of operating laptops and proficient in utilizing Information and Communication Technology."

Based on the findings in the field, the Principals of Public Elementary Schools appointed through Education and Training for Prospective Principals have high managerial competence in improving the quality of education in the schools they lead. The principal of SDN KD 04 with the initials ND stated the following:

"I always prepare school planning by involving teachers in the school. I also try to develop school organizations as needed, make use of existing school resources, and try to create a culture and school climate that is conducive and innovative. I always monitor, evaluate, and report on implementing school activity programs with the right procedures."

Reinforced by the results of observations on the Principal of SDN KD 04 with the initials ND it was found that the ability to manage school facilities and infrastructure looked very optimal. It can see from the development of existing facilities and infrastructure in the school. In addition, ND can also take advantage of advances in information and communication technology to improve learning and school management. It can see when ND operates a laptop as a resource in In House Training activities at his school and is often the secretary for committee activities at the subdistrict level. The results of the documentation study showed that many championships were obtain during the last four years, as evidenced by student competition certificates and trophies in the window of the principal's room and complete school programs in the archive cupboard.

Principals with high managerial competence must be able to define, communicate and articulate the vision of the organization so that subordinates can accept and appreciate the credibility of their leaders [16]. High managerial competence can also be seen in improving the quality of education at SDN KD 02, led by PR, who appoint as the principal of the school through the education and training path in 2013. PR answers the questions from the 
researchers as follows:

"It is true that by becoming a principal through the education and training path before taking office, he gains many theories and skills that can implement directly in the education unit. Good managerial competence will have a very significant impact on the quality of education in schools. During the training for about three months I applied it in the field, and the results did not betray the process. It is an honor for me to be able to manage the education unit well, even though my school's programs are imitated by many other schools."

Principals who carry out their duties well can be seen from how the principal's strategy in improving the quality of education and teacher professionalism [17]. Principal's managerial competence with a good strategy can produce good quality education as well. Principals have a very important role in improving the quality of education as educators, managers, administrators, supervisors, leaders, innovators and motivators [18].

\section{CONCLUSION}

Based on the analysis of research data on the leadership of school principals in improving the quality of education through managerial competencies possessed by school principals in SD Negeri Adipala District, Cilacap Regency, it can conclud that the managerial competence owned by school principals dramatically affects the quality of education in their schools. Good managerial competence of school principals in managing academic units will produce sound output as well. Principal's managerial competence is not generated instantly it needs to go through the stages of the Education and Training Process for Principal Candidates to be more mature in managing academic units based on the theory obtained. Principal leadership with excellent and practical managerial competence believe to improve the quality of education in public elementary schools, especially in Adipala District, Cilacap Regency.

\section{REFERENCES}

[1] Hidayat, A., \& Machali, I. (2012). Pengelolaan Pendidikan, Konsep, Prinsip, dan Aplikasi dalam Mengelola Sekolah Dan Madrasah. Yogyakarta: Kaukaba

[2] Priansa, Donni Juni. (2014). Perencanaan \& Pengembangan SDM. Bandung: Alfabeta.

[3] Mulyasa, E. (2019). Manajemen E Kepemimpinan Kepala Sekolah. Jakarta: Bumi Aksara.

[4] Wibowo. (2016). Manajemen Kinerja. Edisi Kelima. Jakarta: PT. Raja Grafindo Persada.

[5] Martina, K., Hana, U., \& Jiri, F. (2012). Identification of managerial competencies in knowledge-based organizations.Journal of Competitiveness,4(1), 129-142.

[6] Mulyasa, E. (2019). Manajemen E Kepemimpinan Kepala Sekolah. Jakarta: Bumi Aksara.

[7] Moleong, Lexy J. (2017). Metodologi Penelitian Kualitatif (Edisi Revisi). Bandung: PT. Remaja Rosdakarya.

[8] Hamzah, A. (2020). Metode Penelitian Fenomenologi. Kajian Filsafat dan Ilmu Pengetahuan. Malang: Literasi Nusantara.

[9] Cresswell, J. W. (2019). RESEARCH DESIGN. Pendekatan Metode Kualitatif, Kuantitatif, dan Campuran (Edisi 4). Terjemahan Achmad Fawaid. Yogyakarta: Pustaka Pelajar.

[10] Ali, M., Asrori, M. (2014). Metodologi dan Aplikasi Riset Pendidikan. Jakarta: Bumi Aksara.

[11] Sugiyono. (2018). Metode Penelitian Kualitatif untuk penelitian yang bersifat: eksploratif, enterpretif, interaktif, dan konstruktif. Bandung: Alfabeta.

[12] Milles dan Huberman. (1992). Analisis Data Kualitatif. Jakarta: Universitas Indonesia Press.

[13] Sagala, Syaiful. (2009). Manajemen Stratejik dalam Peningkatan Mutu Pendidikan. Bandung: Alfabeta.

[14] Kurniawan, A. (2019). JABATAN KEPALA SEKOLAH; ANTARA JABATAN ADMINISTRASI ATAU JABATAN POLITIK. Jurnal Al Mabhats, 4(2), 147-164.

[15] Arismunandar, A., Nurhikmah H, N. H., \& Ardiansyah, M. (2018). Manajemen Kepala Sekolah (Pengembangan Model Kebijakan Pengangkatan Kepala Sekolah Berbasis Hasil Penelitian).

[16] Multazam, U. (2017). Kepemimpinan Transformasional Kepala Sekolah dan Implikasinya bagi Kinerja Guru. Ta'dibi: Jurnal Manajemen Pendidikan Islam, 6(1), 1-20.

[17] Matondang, N. (2018). Kompetensi Manajerial Kepala Sekolah Dalam Meningkatkan Profesionalisme Guru di SMP Negeri 27 Medan (Doctoral dissertation, Universitas Islam Negeri Sumatera Utara).

[18] Muflihah, A., \& Haqiqi, A. K. (2019). Peran kepala sekolah dalam meningkatkan manajemen mutu pendidikan di madrasah ibtidaiyah. Quality, 7(2), 48-63.

\section{http://jurnalnasional.ump/index.php/dinamika}

